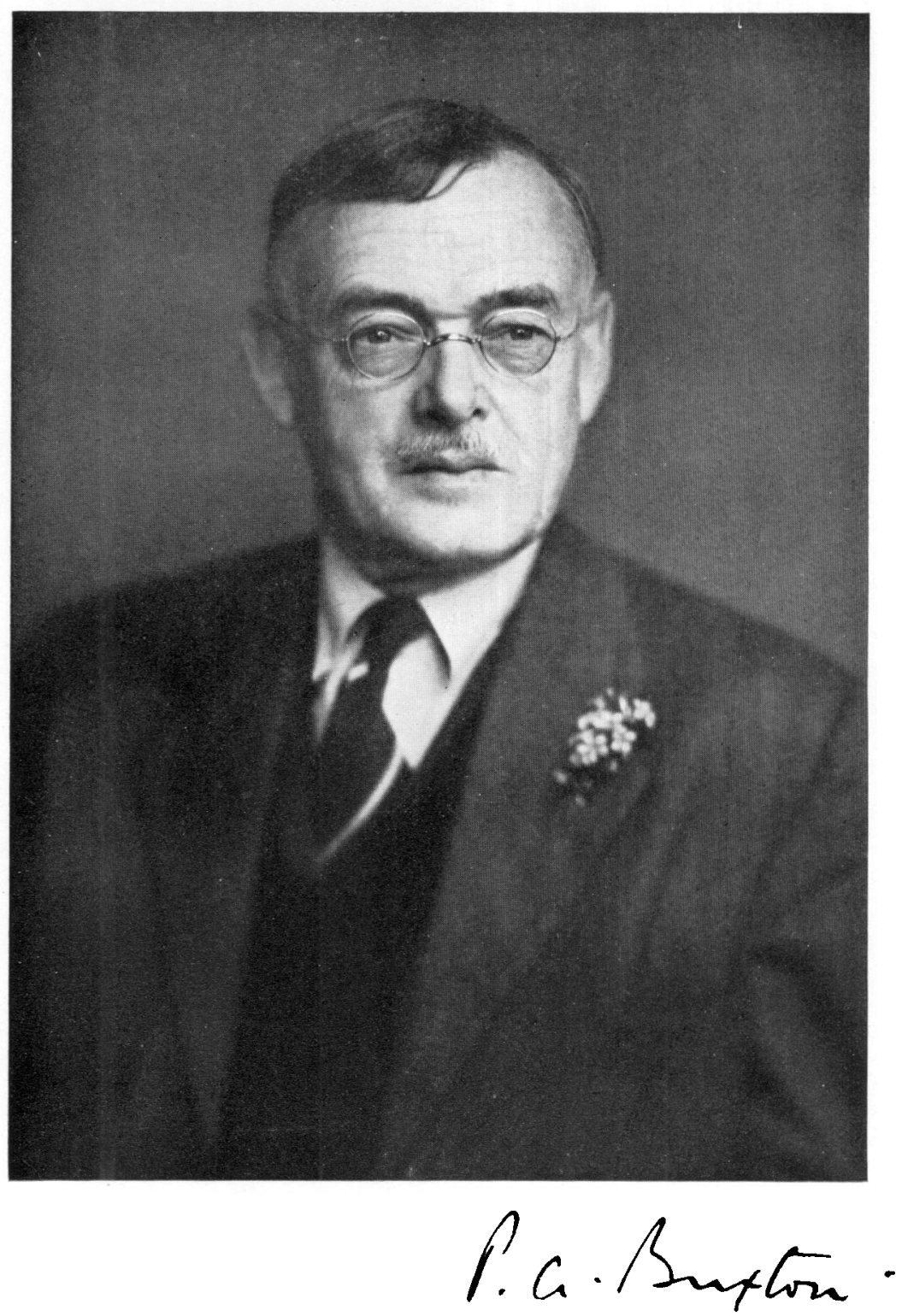




\section{PATRICK ALFRED BUXTON}

$1892-1955$

Patrick Alfred Buxton was born in Hyde Park Street, Paddington, on 24 March 1892, and died at his home in Gerrards Cross, Bucks, on 13 December 1955. His father was Alfred Fowell Buxton, a busy banker and one time chairman of the London County Council, his mother was Violet Jex-Blake.

His father's family was part of that immense group of Buxtons, Gurneys, Barclays, Hammonds, and Hoares, many of them resident in Norfolk and many of them Quakers, whose names appear in the annals of business in this country, in banking, in brewing, in the wool trade and so on, over many centuries. This reputation for acumen in business was often combined with a most practical interest in philanthropy and in political or social reform. One may recall the active part played by Sir Thomas Fowell Buxton in association with Wilberforce in the abolition of the slave trade; and the part played by his sister-in-law Elizabeth Fry in prison reform, and of his grandson Sydney Charles Buxton who sponsored the Wild Birds Protection Act of 1902 and did much to improve conditions of employment. Some branches of the group, for example Hanbury the gardener and Francis Galton, were prominent in science--but to trace a connexion between Patrick Buxton and Galton one would have to go back five or six generations to David Barclay, son of Robert Barclay 'the Quaker apologist'. Among the distinctions of these ramifying families literature is hardly represented and the arts not at all-most were country gentlemen, good naturalists, and strongly averse to things academic.

His mother's family was not numerous; they were mostly farmers and landowners in West Norfolk. His grandfather on his mother's side, Thomas William Jex-Blake was a classical scholar, Headmaster of Cheltenham and Rugby schools and then dean of Wells--with a strong antipathy to biology and the sciences in general. He married a Cordery and had a large family, several of them very able, among whom one might mention Kathleen Jex-Blake, classical scholar and Mistress of Girton, Cambridge, Henrietta Jex-Blake, Principal of Lady Margaret Hall, Oxford, and Arthur Jex-Blake, an able scholarly medical man.

There were three children in the family of Alfred Fowell Buxton, of whom Patrick was the eldest. His brother Denis Alfred Jex Buxton (b. 1895), also a keen naturalist, followed a career in the City; his sister Violet Elizabeth (b. 1900) remained at home and died a few years ago. Until Patrick was eight years old the family lived in London-in the days when it was still possible for a small boy to ride his pony from the Edgware Road across to the Marble Arch. But there were long summer holidays in the countryside of Hertfordshire. The family then moved to completely rural surroundings, several miles from the railway, at Chigwell in Essex.

Outside his busy life as a banker, Alfred Fowell Buxton was fond of gardens, shooting, birds and moths and this was a strong influence on the small boy. There 
was a family tradition of knowing plants, animals and birds and of collecting them. The young naturalists were most industrious, preserving and labelling and 'making collections'; there was a family Natural History Journal (an old Quaker custom) and at rare intervals they would record the catching of a water shrew, seeing a rare bird or finding a flower at an unusual date-but no one guided them further to think about their specimens or use them.

Patrick Buxton was educated at home until the age of ten. By that time he had already started on Greek-and had been imbued with a strong and lasting prejudice against the classical languages. This was followed by three years at a preparatory school with more classics and little profit, and from 1905 to 1911 he was at Rugby. Under the strong Jex-Blake influence he was kept on the classical side, which bored him to the extent that he was nearly superannuated. Indeed, looked at on the surface his school days were not a success. Short sighted, untidy in appearance, a near failure at work and with no aptitude for games, he became something of a butt-the sort of boy whose subsequent distinction his school fellows find hard to credit.

There was one bright spot. This strange youth was allowed to neglect organized games for the pursuit of natural history; he ran the school Natural History Society and published many local observations in their annual report. Of formal teaching of biology there was none, and scholarships and prizes did not come Patrick Buxton's way.

In October 1911, again in accordance with a strong family tradition, he went up to Trinity College, Cambridge. His tutor was the physiologist Walter Fletcher, to whom he explained that he was a complete failure at academic work and proposed to take a Pass Degree in biological sciences. But Fletcher insisted that he should at least try for a Tripos and that if that proved impossible they could think about the Pass Degree after a year.

That was an encouraging start; for Buxton quickly discovered that he had been completely misled about his abilities-that he could actually do intellectual work in biology as well as the next man; and in 1914 he obtained a 1st class in Part I of the Natural Sciences Tripos with zoology, botany and physiology as his subjects.

About November 1913 Buxton has added medicine to his burdens-under a philanthropic urge that this was of more use to humanity than pure biology. And on the outbreak of war in August 1914 he enlisted as a private in a Field Ambulance, thinking that a medical student should be of some use in such a place. But in January of the following year he was sent back to his medical studies.

In the summer of 1915 he rather rashly sat for Part II of the Natural Sciences Tripos in zoology, for he had been mainly working on his anatomy and physiology for the 2nd M.B. examination, and it gives some indication of the enthusiasm with which Buxton was developing his newly discovered powers, that he not only passed the 2nd M.B. but obtained a 1st class in the Tripos.

In the old Department of Zoology at Cambridge in those days, conditions were so informal that the keen undergraduate could sit about and pick up all the methods that he wanted and learn informally from men a little older than himself in a way 
that is less easy in these crowded days. In physiology Buxton owed much to his informal contacts in this way with Keith Lucas, in the days when he and A. V. Hill were doing such brilliant work in such unsavoury surroundings.

In the autumn of 1916 Buxton was elected to a Fellowship at Trinity. This was awarded mainly for a piece of undergraduate research on the brain of the primitive moth Micropteryx. The idea of this research was entirely his own and was not very logical: the object was to attempt to throw light on the structure of the insect brain studying the brain in a primitive insect-but Micropteryx, though a primitive Lepidopteron, is a member of one of the more recently evolved groups of insects. It must have been difficult work to assess, remarkable chiefly for the extremely difficult conditions, in camp and so on, under which it was carried out; but Stanley Gardiner, who was one of the assessors, and who must have started without any knowledge of the subject, doubtless recognized the potentialities of the author.

Buxton proceeded to St George's Hospital and qualified in medicine (M.R.C.S., L.R.C.P.) in 1917. He at once took up a commission in the Royal Army Medical Corps, and was posted to Mesopotamia and North West Persia. Often there was very little to do and, in consequence, plenty of opportunity for the enterprising naturalist to collect great numbers of insects, bird skins and the like. The censor raised no objection to the provision of adequate data and most of the labelled specimens reached home safely. All this material, with much else obtained by other collectors, formed the basis of a survey of the fauna of Iraq published by the Bombay Natural History Society. It also provided a fine training in the natural history of desert animals, although, being constantly on the move, he was unable to do any serious biology. This lasted until the end of 1919 .

During 1920 and 1921 Buxton was back in England, resident mostly in Cambridge where he was working on the speciation of the itch mites Sarcoptes in Nuttall's laboratory. He also took the course in tropical medicine in Londonwhere, according to tradition, he was chiefly noted for his habit of arriving late and reading the newspaper during lectures-characteristics which in later times he found impossible to tolerate in students. Which goes to show how our point of view changes with the years!

In March 1921 Buxton accepted the post of entomologist in the Medical Department in Palestine. Here he remained for two and a half years, devoting himself on the one hand to the survey of malaria and other parasitic diseases (sound but unenlightened work according to his own assessment, for he had no contact with anyone who really knew about malaria) and on the other to the study of desert and semidesert faunas. The output from two years' work was remarkable and culminated in the production of what he himself has called that 'vigorous young man's book' on Animal Life in Deserts.

By the summer of 1923 Buxton was beginning to feel that he had been enough in Arab and Persian lands, and that if he was to be a real medical entomologist he ought to see the damp tropics. This opportunity came when he accepted a temporary post under the London School of Tropical Medicine to lead a research expedition to Samoa. The purpose was to continue the Manson tradition and to pursue the 
study of filariasis. The plan was somewhat vague: perhaps to control the insect vector, perhaps to do work on its biology. Anyhow, he had plenty of equipment, generous terms and complete independence; so that the vagueness of plan was probably what he would have wished. He chose his own assistant, G. H. E. Hopkins, a careful worker and a good naturalist, and together they spent two years in Samoa.

During that time an immense amount was accomplished. The general biology of Aedes scutellaris (variegatus), which transmits the infection, was known from the work of Manson-Bahr and others, but they carried out a great many simple experiments in an attempt to analyse the specialized selection of breeding places by the egg-laying female - a line of study which has been much developed since but was new at that time. Buxton also visited the New Hebrides for a few months and made a useful survey of the general incidence of malaria, filariasis and other diseases, and he spent a month touring the Ellice and Tokelau Islands in a mission ship. In this way he was able to study a true sample of Oceania and became familiar with the ways of life of Polynesians and Melanesians in the widely dissimilar types of island. All these surveys and experiments were published in two large memoirs by the London School of Hygiene and Tropical Medicine.

As a side line Buxton and Hopkins collected Samoan insects. Instead of the very restricted fauna that would all go into 'two or three cigar boxes' which some entomologists had foretold, they collected about 1600 insect species, many of them new to science. All were eventually listed or described in a series of memoirs on The Insect Fauna of Samoa and published in good style by the British Museum. All this amounted to a substantial achievement which entailed the co-ordination of the work of experts in all parts of the world, and in the result the insects of Samoa were better known than those of nearly all the other island groups in Oceania.

The Pacific trip lasted from the end of 1923 to January 1926. Buxton was beginning to feel that it was about time to settle in England. In January 1917 he had married Muryell Gladys Rice, daughter of the Rev. Hon. William Talbot Rice (the son of a Baron Dynevor - a family of Welsh landowners and coalmine owners) and Marian Gurney. Buxton and his wife were therefore second cousins and doubtless related in other ways, their large connexions having intermarried frequently and over a long run of years. They had gone out to Palestine with one small baby, a son, and returned with two. A daughter was born in Samoa. These simple statements will perhaps serve to convey the extent to which Buxton was indebted to his wife during these rather hectic years. Though not sharing his scientific interests she always provided a home and a background and shared to the full his interest in the places and people around them.

By the time Buxton was back in London in January 1926 he had been appointed head of the Department of Entomology in the new London School of Hygiene and Tropical Medicine, which had absorbed the old London School of Tropical Medicine and was now gathering itself together under Andrew Balfour. The great new building in Gower Street was only on paper, and in an early state. Several departments (bacteriology, epidemiology) had not yet been formed and when formed had to be housed separately, in several parts of London. 
The Department of Entomology in the old School had been the creation of Colonel A. C. Alcock - an able and scholarly medical entomologist, much loved and respected, but sadly aged by the time of his retirement. All the departmental letters, many of them unopened, were kept in a soap box. There was not one single piece of graduated glassware, no balance. But, with the large Rockefeller donation, there was plenty of money available for equipment.

At this time Buxton wrote a letter to Nature in which he put forward the view that 'real progress will not be made in applied entomology until...we devote time and labour to the study of the fundamentals of insect physiology'. Following this up he persuaded the Board of Management that 'the contribution of the School to medical entomology should be to go deep and to produce a science of insect physiology'-as a basis for the understanding of insecticidal action and for the interpretation of biology in the field. Walter Fletcher, who was now Secretary of the Medical Research Council and a very active member of the Board of Management of the School, strongly supported Buxton in this point of view.

In advertising for an assistant, with a very wide range of desirable qualifications, a special point was made of experience in biochemistry or some side of physiology -a highly original requirement in those days when filling a post in medical entomology. Among the applicants was V. B. Wigglesworth, "who had had a good academic career, had written half a dozen papers, some jointly with J. B. S. Haldane, was about to qualify in medicine-and was very silent and unimpressive at interview. Against him were middle-aged people, with lots of field experience in anti-malarial work, etc.' Buxton, very young and very definite, strongly supported Wigglesworth at the appointing committee; he was backed up by Walter Fletcher and the appointment was made-although, as Balfour did not hesitate to point out to the successful candidate, it was a very queer one. These facts are perhaps worth putting on record because Buxton always rightly felt that one of his most valuable contributions to entomology was the impetus he had given to the study of insect physiology, and this was his first step. In this way began the happy (though not uncritical) association between the present writer and Patrick Buxton that was to last for nineteen years.

There followed the busy period of planning and equipping the new Department, of building up the teaching courses in medical entomology, and of putting the idea of research in insect physiology into practice. Buxton himself took up the study of the relations of insects to climate, their water and temperature relations. More will be said about this when we come to discuss Buxton's scientific contributions; it was the general field of research that occupied his attention between 1926 and 1939. Other appointments were made, the most notable of which were that of K. Mellanby who joined Buxton with the support of the Medical Research Council to extend the work on water and temperature relations-which he did to very good purpose-and R. P. Hobson whom the Empire Marketing Board financed to study digestion and nutrition in Calliphoridae.

By 1931 Buxton began to feel the need to travel once again. He made a brief trip to Palestine in an attempt to study the microclimate in which the fleas of rodents actually exist in hot dry countries. In 1933, in company with a young 
graduate D. J. Lewis, a distant cousin, he undertook a more serious expedition of seven months in Northern Nigeria, where they carried out extensive observations on the climatic conditions in which the several species of tsetse flies develop in this hot dry part of Africa. In the same year he was made Professor in the University of London.

Throughout these years a long series of entomologists from all parts of the tropics visited the laboratory for short periods. And many others, after a period of training in laboratory research, have had distinguished careers as medical entomologists: D. J. Lewis, R. C. Muirhead Thomson, A. Haddow, E. P. Hodgkin, and many more. In medical entomology the most important enterprises were a detailed investigation of the physiology and ecology of the bed-bug, carried out by C. G. Johnson with the support of the Medical Research Council (1935-40), a study of the factors concerned in the spreading of anti-malarial oils by D. R. P. Murray supported jointly by the major oil companies (1936-40), and an analysis of the egg-laying behaviour and biology of Anopheles minimus in Assam by R. C. Muirhead Thomson under a grant from the Royal Society.

For a year or two in the late nineteen thirties Buxton had been working on a projected text-book of medical entomology. One chapter was finished, that on the louse. On the outbreak of war in September 1939, thinking, as many did, in terms of the earlier world war and picturing again a stationary warfare in trenches, Buxton decided to devote the main effort of his department to the improvement of practical measures against the louse. The chapter in the book was rapidly expanded to form an up-to-date monograph on the subject and within seven weeks of sending to the press it was published.

Twenty years had gone by. since there had been any serious work on the control of lice. The accumulated experience of twenty years in applied entomology was available for application in this field. Buxton appreciated that the great shortcoming of all the de-lousing procedures developed during the 1914-18 war was that they had no lasting effect: immediately the man returned to the trenches he was re-infested. The answer appeared to be a 'lasting' insecticide with which the clothing could be impregnated. There had been considerable advances in insecticides in the course of twenty years and particular attention was given to the organic thiocyanates.

Buxton's methods of conducting this investigation were energetic, unconventional and Buxtonian. They were not very popular with the authorities of the London School of Hygiene. By means of contacts with relieving officers and the keepers of common lodging houses, he built up a clientele of verminous tramps who (for a small consideration) used to flock to the 'louse clinic' in the School. Here they were given new shirts for old, or their shirts were sprayed or dusted with various new chemicals. Meanwhile everyone possible, including most of Buxton's family, were pressed into the service of rearing lice in small containers under their socks or vests to provide the material for controlled experiments in the laboratory.

The unsavoury and unconventional aspects of this enterprise appealed to the showman in Buxton; but it was all most useful work. Only one thing was lacking 
- a suitable insecticide. The thiocyanates were effective in killing lice but they were too irritating to the human skin for general use. On the other hand, incorporated in a hair oil, they proved invaluable in the treatment of head lice which were a major problem at this time both among the children evacuated from the large towns and the girls recruited to the Women's Services. He developed a pleated impregnated belt which could be worn beneath the clothing-but this also proved too irritating during sweating -as became only too apparent when a certain Highland regiment carried out an exercise on the Cairngorms wearing the impregnated belts.

By 1942 this work had reached a deadlock. Then we were approached by Dr G. A. Campbell of the Geigy Chemical Company in Manchester (he had been referred to us by Dr F. Tattersfield) with the report that their parent company in Switzerland had produced a new synthetic insecticide which they wished to make available to the western allies. We read the patent specification of 'Gessarol', and were frankly sceptical; for this material, non-irritating and apparently harmless to man, non-volatile and long-lasting, highly toxic to insects, was exactly what Buxton had visualized as the lasting insecticide against the louse. Of course the material had to be tested. A small sample was synthesized at Manchester; a kilogram sample was obtained from Switzerland. Both had the same properties; the material was even more promising than we could have hoped. Almost at the same time the branch of Geigy in the United States brought the new insecticide to the notice of the American authorities. They were equally impressed. Soon afterwards, at a meeting of the Insecticides Research and Development Committee, the Chairman, Professor (later Sir Ian) Heilbron christened the new insecticide 'DDT'. The name was accepted by the Americans and the rest of the story, which marked the beginning of a new era in applied entomology, is well known. Buxton's preparatory work proved very useful in the early exploitation of DDT.

Buxton's interest and energy was by no means confined to the louse problem. On the outbreak of the war he established close relations with the medical departments of the War Office, Admiralty and Air Ministry. He organized series of lectures to nurses and shelter marshals. He persuaded Sir Edward Mellanby as Secretary of the Medical Research Council to set up an Entomological Sub-Committee of their Military Personnel Research Committee, with Buxton as chairman. This proved a useful medium during the early war years for advising the Service Departments on modern methods in medical entomology. It was not so effective as it might have been for it had no means of ensuring that its recommendations were carried out. That defect was later remedied by an ingenious administrative device in a new committee, the Pyrethrum Development Panel (later the Insecticides Research and Development Committee) under the chairmanship of Professor Heilbron. It was characteristic of Buxton that he was not interested in the slightest degree in his personal position in these affairs. He was concerned only in improving the methods of medical entomology in the Services.

Buxton certainly enjoyed his war. It provided all the opportunities he could desire for deploying his unbounded energy. Work was initiated on fumigation against lice in clothing and bedding, on mosquito repellents, on mosquito and 
fly sprays, on the control of bed bugs in air-raid shelters, on the control of head lice and other projects. He made trips to the United States as a member of a mission from the Ministry of Production to agree on the sharing of pyrethrum supplies, to Egypt to try out the louse belts (which proved of real value when used among native labour forces in the Eastern Mediterranean), to West Africa to take part in trials of aerial spraying against mosquito larvae. His ambition of making a trip to Russia to demonstrate the new methods of controlling bed bugs and body lice was thwarted only by Madame Maisky (the wife of the Russian Ambassador), who solemnly assured him that neither of these insects existed any longer in Russia.

At the end of the war in 1945 when Buxton had to re-start his department on a peace-time footing, he felt disinclined to go back himself to physiological research. He even suggested more than once in conversation that the study of insect physiology had not yielded quite what he had hoped. But he attracted workers in many sides of medical entomology and his department was never more active. It was at this time that as a member of the Colonial Medical Research Committee (of the Medical Research Council jointly with the Colonial Office) Buxton was invited to carry out two extensive tours in East Africa, from Kenya and Uganda to Zululand and Bechuanaland, to report on the tsetse fly and trypanosomiasis with reference to the organization of research and control. These long journeys occupied much of 1945 and 1946.

The last decade saw the building up of the Department of Entomology as a most active centre of teaching and research. Buxton became increasingly in demand as an adviser and as a member of committees. He had been elected a Fellow in 1943 and served on the Council of the Royal Society for 1951-53. He was appointed a member of the Medical Research Council in 1945 and served on their Committees dealing with Typhus, Malaria and Colonial Medical Research, as well as the Tsetse Fly and Trypanosomiasis Committee of the Colonial Office. He served on the Council of the Royal Society of Tropical Medicine and of the Royal Entomological Society, of which he was President in 1942 and again in 1953-55. He was made a C.M.G. in 1946. In 1949, on the occasion of the jubilee of the Liverpool School of Tropical Medicine, he was one of the recipients of the Mary Kingsley Medal. In 1951 he received a Linnean medal and in 1953 the Gold Medal of the Linnean Society. In 1950 he was elected to Foreign Membership of the Société de Pathologie Exotique. During these latter years, however, Buxton continued to travel: to the Southern Sudan to study tsetse flies, to Canada to see the black-fly and mosquito problems of the far north, to Central America to gain first-hand knowledge of an epidemic of jungle yellow fever, and to Malaya. Indeed, between 1940 and 1954 there was no year in which he did not pay at least one visit to the tropics or sub-tropics.

\section{Scientific work}

The most striking feature of Buxton's output of scientific research, extending over forty years, is its diversity. There are papers dealing with pure taxonomy and descriptive entomology, papers on applied entomology in agriculture and medicine, on insect physiology and ecology - particularly on the border line between these two, where the study of physiology in the laboratory and of the 
micro-climatic conditions in the actual environment serve to define the limitations to the existence of a given insect in the field. Interspersed with these are papers on the birds or on the people in the many lands he visited, on geography and ethnology.

During the period of his most intensive concentration on research, the twelve years before the second world war, Buxton's main interest was in those physiological factors which determine the survival and increase of insect populations under different conditions of climate, particularly the effect upon them of different temperatures and humidities. He made clear that for many purposes the saturation deficiency of the air is the most informative measure of its drying power in relation to the insect, and he repeatedly emphasized the importance of considering the 'micro-climate'- the climate in the actual spot when the insect rests-rather than the climate of the meteorologist.

In my view, however, Buxton's claims to distinction do not lie in the realm of experimental science. Without question he did useful work in that field. His experimental work on the relation of insects to climate is not negligible in itself and its influence on the work of others perhaps even more important, both in his immediate circle and among entomologists in general. His contributions to the applied entomology of filariasis, malaria and the louse-borne fevers were imaginative and timely. But these do not by themselves represent an outstanding achievement.

It is probably true to say that, except in so far as they contribute to theories and generalizations, the scientific mind is not interested in facts. But for Buxton, I believe, the scientific theory had less appeal than the facts themselves. This attitude is characteristic of the naturalist; and in my opinion it is as a naturalist that Buxton was outstanding. Whatever he might be doing, in whatever part of the world he might be, he would be sure to produce observations on the local natural history of great interest and originality. His war-time experiences in Persia and Iraq, and after the war in Palestine, resulted in the production of his book on Animal life in deserts. This has become a classic; and after a continuous demand lasting for thirty years, it was reprinted in 1954. In Samoa, apart from the extensive field work required for the Insects of Samoa, Buxton made the remarkable discovery of a truly marine Chironomid midge, Pontomyia natans Edwards, in which not only is the larva adapted to developing in salt water (a phenomenon not entirely without precedent) but the adult midge itself is a submarine creature which swims actively in the strong tidal currents.

In every country he visited, Buxton contributed useful observations on the birds and plants; and these catholic interests extended to the human populations. In 1921 he was writing on the way of life of the Marsh Arabs of Lower Mesopotamia; in 1926 and 1929 he writes a sympathetic account of depopulation in parts of Melanesia and Polynesia. And his more professional studies on the incidence of malaria and filariasis in the South Pacific are illuminated at every point by an understanding of the habits and outlook of the local population.

This feeling for natural history, ethnology and geography was coupled with an interest in language. Buxton early mastered Arabic and this helped greatly in putting him en rapport with Arab people both in the Iraq and Palestine days and 
later in Egypt. And when in Samoa he went some way towards mastering that difficult language - the 'pidgin' of the South Seas.

These wide interests in anthropology, geography and animal and plant ecology provided the ideal foundation on which to base a really comprehensive account of the tsetse fly problems of tropical Africa. Before the war of 1939 Buxton had started on an ambitious text-book of medical entomology. It was never completed. The chapter on the louse was quickly turned into an admirable practical monograph and published as The louse soon after the outbreak of the war. The chapter on the tsetse fly grew into the great memoir of 800 pages published by the London School of Hygiene and Tropical Medicine in the last year of Buxton's life.

This Natural history of the tsetse flies is Buxton's magnum opus. Going out to Northern Nigeria for some seven months in 1933 with D. J. Lewis, he had had some first-hand experience of two species of Glossina under field conditions, and had made a substantial contribution to their physiology in relation to climate. This work served to emphasize that in much of its range the tsetse fly is on the border line of existence so far as climate is concerned; it is able to maintain itself only because the 'micro-climate' is within the favourable range. This discovery has provided a useful lead in the control of the tsetse fly. As T. A. M. Nash, K. M. Morris and others have found, when the undergrowth in the thickets is cleared away, without touching the larger trees, the climate in the actual spots where the tsetse fly lives and breeds becomes too unfavourable and the fly dies out. Then Buxton's extensive tours in East Africa on behalf of the Colonial Office during 1945 and 1946 gave him the opportunity of seeing the very different and diverse conditions in those regions, at first hand, and in the company of people who had been studying them for many years. Bringing his fresh outlook and wide experience to bear, and reading widely in the copious literature of the subject, he was able to achieve a masterly synthesis, in which the physiology and ecology of the many species of tsetse flies are linked with the climatic and vegetational characteristics of the various regions, and these again with the ways of life of the diverse peoples and with the incidence of sleeping sickness and trypanosomiasis in domestic animals. This book combines in a remarkable degree an immense amount of local detail with the guiding principles and generalizations derived from ecological studies. In view of Buxton's early advocacy of the study of insect physiology it is good to see the extent to which laboratory work on the tsetse fly has provided a basis for understanding its ecology.

\section{Personal record}

Patrick Buxton had a strong and distinctive personality. Completely honest, with definite personal views, he was a man to be relied upon. But for many who came into contact with him the most notable feature about Buxton was his manner -the well-known 'Buxtonian manner', a characteristic mixture of irony and display, infused with a quick wit and a well-developed sense of humour. His sharp sarcastic tongue was well known in committee. I always supposed that this manner, which could strongly antagonize those who did not see beyond it, was a 
product of his school days, an intellectual method of protection against a rough world. But very many people, in all parts of the world, were not misled by this odd veneer and Buxton had friends everywhere. For the real and outstanding qualities in Buxton's character were his honesty of purpose and his thoughtfulness for others-a deep unconscious loyalty to a long family tradition.

Buxton's interests were at once broad and narrow. He was, as we have seen, intensely interested in all sides of the natural history of plants and animals, in geography, meteorology, and in the life of primitive peoples and their languages. At home he was an enthusiastic gardener, cultivating rare and unusual plants in his fine garden at Gerrards Cross and never happier than when showing them to the many friends who were invited down there or digging them up for these friends to take away. He usually wore an uncommon flower or a sprig from some rare plant in his buttonhole.

Outside his special subjects Buxton found it difficult to be interested. Music he disliked, and anyone who was interested in poetry or philosophy he would regard as distinctly abnormal; he was much attached to and well informed about the arts and crafts of Persia, less sympathetic to other forms of art. In science itself he always seemed to me to be more fascinated by the multifarious details that appeal to the naturalist than by the ideas and generalizations that are the objectives of the scientist and philosopher. In the day-to-day pursuit of his researches he usually preferred to collect facts and to sort them out with the aid of statistics than to devise experiments.

Buxton as this record has set out to show, was a great naturalist; and in common with that rare breed, he had a fine command of English and wrote in a lucid unaffected style. Even in his massive work on the tsetse fly the high quality of the writing is maintained and will ensure that this book has an honourable future. He was equally effective as a speaker, with a vivid descriptive power and a way of presenting even familiar matters in a new light.

Behind all his professional activities Buxton was a family man. Happily married at an early age, he had a family of two sons and four daughters. These have taken up very diverse careers. Only one of them, the second boy, Andrew, became a professional biologist. Andrew Buxton bore a striking resemblance to his father in general appearance and in his quick wit and lively sense of humour, so that people knew on sight whose son he was. After running the Natural History Society at Rugby and graduating at Trinity College, Cambridge, Andrew Buxton had started on research in East Africa, studying the natural history of monkeys and other potential reservoirs of the yellow fever virus-when he was suddenly struck down by poliomyelitis. The death in 1952 of this son in whom he had been able to re-live his own enthusiasms was a terrible blow to Patrick Buxton. It seemed for a time that he would never recover, and when he did so it was apparent to all his friends that many of Buxton's asperities had gone and the fine quality of his nature was there for all to see.

It is not usual to use the word tragedy when writing of the death of a man of sixty-three whose main work has been accomplished. But in his last few years Buxton was turning his attention to a new branch of natural history, that of the 
Mycetophilidae - with the idea of providing a new field of interest for his retirement. He was already producing valuable results and when he died on the threshold of what promised to be a new career, those who had appreciated his kindness and unselfishness for many years felt his death as a tragedy.

V. B. WIGGLESWORTH

\section{BIBLIOGRAPHY}

1911. (With D. A. J. Buxton.) Greek Lepidoptera in April, 1911. Ent. Rec. 24, 59.

1914. (With D. A. J. Buxton.) Late summer in Norway. Ent. Rec. 26, 153.

1914. Notes on Tunisian and Algerian insects. Ent. Rec. 26, 63.

1916. (With C. B. Williams.) On the biology of Sphodromantis guttata (Mantidae). Trans. R. Ent. Soc. Lond. 86.

1917. On the protocerebrum of Micropteryx (Lepidoptera). Trans. R. Ent. Soc. Lond. pp. 112-53.

1919. (With T. A. Chapman.) Contributions to a life-history of Tarucus mediterraneae Bethune-Baker. Ent. Mon. Mag. 55, 163-73.

1920. The capitulum of Psoroptes (Acarina), Parasitology, 12, 334-6.

1920. The importance of the house-fly as a carrier of E. histolytica. Brit. Med. J. pp. 1-7.

1920. Body-lice under summer conditions in Mesopotamia. Parasitology, 12, 173-4.

1920. Carriage of coliform bacilli by the Oriental Hornet (Vespa orientalis Fabr.). J. Hyg., Camb., 19, 68-71.

1920. A liparid moth (Ocnerogyia amanda Staud.) destructive to figs in Mesopotamia. Bull. Ent. Res. 11, 181-6.

1920. Insect pests of dates and the date palm in Mesopotamia and elsewhere. Bull. Ent. Res. 11, 287-303.

1921. Animal oecology in deserts. Proc. Camb. Phil. Soc. 20, 388-92.

1921. The external anatomy of the Sarcoptes of the horse. Parasitology, 13, 114-51.

1921. Butterflies of Gilan, N.W. Persia. Ent. Rec. 33, 29-32.

1921. Notes on birds from Northern and Western Persia. J. Bombay Nat. Hist. Soc. pp. 95-133.

1921. (With V. H. W. Dowson.) The marsh Arabs of Lower Mesopotamia. Indian Antiq. 50, 289-97.

1922. On fish and mosquitos in Palestine. Bull. Ent. Res. 13, 203-4.

1922. (With K. S. KrikorIaN). On Schistosomiasis in Palestine. Trans. R. Soc. Trop. Med. Hyg. 16, 162-6.

1923. On predicting the seasonal prevalence of an insect. Trans. R. Soc. Trop. Med. Hyg. 16, 465-8.

1923. Anopheles larvae from Palestine and elsewhere. Bull. Ent. Res. 14, 75-82.

1923. Canine leishmaniasis not found in Jerusalem. Trans. R. Trop. Med. Hyg. 17, 212.

1923. Two further cases of co-ordinated rhythm in insects. Entomologist, 56, 271.

1924. Applied entomology of Palestine, being a report to the Palestine Government. Bull. Ent. Res. 14, 289-340.

1924. Heat, moisture and animal life in deserts. Proc. Roy. Soc. B, 96, 123-31.

1924. The temperature of the surface of deserts. J. Ecol. 12, 127-34.

1924. Habits of some Tenebrionid beetles. Ent. Mon. Mag. 60, 3-7.

1924. Physical factors controlling harvesting in an ant. Trans. R. Ent. Soc. Lond. (1923), Pts III, IV.

1924. A key to the fourth stage Anopheles larvae of Palestine (Dipt.). Bull. Soc. ent. Egypte (1923), pp. 45-51.

1924. (With B. P. Uvarov.) A contribution to our knowledge of Orthoptera of Palestine. Bull. Soc. ent. Egypte (1923), pp. 167-214.

1925. (With G. H. E. HopkIns.) The early stages of Samoan Mosquitos. Bull. Ent. Res. 15, 295-301.

1925. (With G. H. E. Hopkins.) Race suicide in Stegomyia. Bull. Ent. Res. 16, 151-3.

1926. The depopulation of the New Hebrides and other parts of Melanesia. Trans. $R$. Soc. Trop. Med. Hyg. 19, 420-454. 
1926. The colonization of the sea by insects. Proc. Zool. Soc. pp. 807-14.

1926. The radiation integrator in vacuo, an instrument for the study of radiant heat received from the sun. J. Hyg., Camb., 25, 285-94.

1926. Applied entomology. Nature, Lond., 117, 623-4.

1927. Scorpionoidea. Insects of Samoa and other Samoan terrestrial Arthropoda. Brit. Mus. $1,14$.

1927. A parasitic fibroma on equines in Samoa. Parasitology, 19, 352.

1928. Two notes from Oceania. Man, p. 57.

1928. Scorpionoidea; Siphonaptera; Anoplura. Insects of Samoa. Brit. Mus. Pts 7-9.

1928. Sur les moustiques de Tahiti et du groupe des îles de la Société. Bull. Soc. Etud. oceanien. 21, 306.

1928. An aspirator for catching midges. Trans. R. Soc. Trop. Med. Hyg. 22, 179.

1929. Further data relating to Melanesian populations. Trans. R. Soc. Trop. Med. Hyg. 22, 435.

1929. Sarcophagidae. Insects of Samoa. Brit. Mus. Pt. 6.

1930. Evaporation from the Mealworm (Tenebrio: Coleoptera) and atmospheric humidity. Proc. Roy. Soc. B, 106, 560-77.

1930. The biology of the blood-sucking bug, Rhodnius prolixus. Trans. R. Ent. Soc. Lond. 78 , 227-34.

1930. Description of the environment. Insects of Samoa. Brit. Mus. Pt. 9.

1931. The law governing the loss of water from an insect. Proc. R. Ent. Soc. Lond. A, 6, 27-31.

1931. The thermal death-point of Rhodnius (Rhynchota, Heteroptera) under controlled conditions of humidity. J. Exp. Biol. 8, 275-8.

1931. The measurement and control of atmospheric humidity in relation to entomological problems. Bull. Ent. Res. 22, 431-47.

1931. Studies on the biology of fleas. Lond. Nat. pp. 39-42.

1932. The climate in which the rat-flea lives. Indian J. Med. Res. 20, 281-97.

1932. The proportion of skeletal tissues in insects. Biochem. J. 26, 829-32.

1932. Ancient workings of insects, perhaps bees, from Megiddo, Palestine. Proc. R. Ent. Soc. Lond. 7, 2-4.

1932. Les conditions de la vie animale dans les deserts. Le Sahara, Paris (Soc. Geogr.), pp. 1-61.

1932. Terrestrial insects and the humidity of the environment. Biol. Rev. 7, 275-320.

1932. The relation of adult Rhodnius prolixus (Reduviidae, Rhynchota) to atmospheric humidity. Parasitology, 24, 429-39.

1932. Climate in caves and similar places in Palestine. J. Anim. Ecol. 1, 152-8.

1933. The effect of climatic conditions upon populations of insects. Trans. R. Soc. Trop. Med. Hyg. 26, 325-64.

1934. (With K. Mellaniy). The measurement and control of humidity. Bull. Ent. Res. 25, 171-5.

1934. (With D. Aubertin.) Cochliomyia and myiasis in tropical America. Ann. Trop. Med. Parasit. 28, 245-54.

1934. (With D. J. LEwIs.) Climate and tsetse flies, laboratory studies upon Glossina submorsitans and tachinoides. Phil. Trans. B, 224, 175-240.

1934. Further studies upon chemical factors affecting the breeding of Anopheles in Trinidad. Bull. Ent. Res. 25, 491-4.

1935. Notes on birds from Northern Nigeria. Ibis, pp. 101-10.

1935. Seasonal changes in vegetation in the North of Nigeria. J. Ecol. 23, $134-9$.

1935. Summary. Insects of Samoa. Brit. Mus. Pt. 9.

1935. Changes in the composition of adult Culex pipiens during hibernation. Parasitology, 27, 264-5.

1935. The effect of Proteosoma upon the survival of Culex. Parasitology, 27, 548-50.

1936. Studies on populations of head lice (Pediculus humanus capitis: Anoplura), I. Parasitology, 28, 92-7.

1936. Studies on soils in relation to the biology of Glossina submorsitans and tachinoides in the North of Nigeria. Bull. Ent. Res. 27, 281-7.

1936. Breeding rates of domestic rats trapped in Lagos, Nigeria, and certain other countries. J. Anim. Ecol. 5, 53-66.

1936. Prolonged larval life of an African Stratiomyiid. Proc. R. Ent. Soc. Lond. A, 11, 6-12. 
1937. The numbers of males and females in natural populations of head-lice (Pediculus: Anoplura). Proc. R. Ent. Soc. Lond. A, 12, 12-14.

1937. Domestic insects and atmospheric humidity. J. Instn Heat. Vent. Engrs, 5, 80-1.

1937. (With F. MARSH.) Measurements of temperature and humidity between the clothes and the body. J. Hyg., Camb., 37, 254-60.

1938. Studies on populations of head-lice (Pediculus humanus capitis: Anoplura). II. Parasitology, 30, 85-110.

1938. Studies on the growth of Pediculus (Anoplura). Parasitology, 30, 65-84.

1938. Anopheles (Diptera) and the species problem. Proc. Zool. Soc. Lond. 108, 57-60.

1938. Quantitative studies on the biology of Xenopsylla cheopis (Siphonaptera). Indian $J$. Med. Res. 36, 505-30.

1938. The formation of species among insects in Samoa and other oceanic islands. Proc. Linn. Soc. Lond. 150, 264-267.

1940. The louse: present knowledge and future work. Trans. R. Soc. Trop. Med. Hyg. 33, 365-88.

1940. Derris as an insecticide. Brit. Med. J. p. 232.

1940. Temperatures lethal to the louse. Brit. Med. J. p. 341.

1940. Studies on populations of head-lice (Pediculus humanus capitis: Anoplura). III. Material from South India. Parasitology, 32, 296-302.

1940. The biology of the body louse (Pediculus humanus corporis: Anoplura) under experimental conditions. Parasitology, 32, 303-12.

1940. The control of lice. Brit. Med. J. p. 806.

1941. On the occurrence of the crab-louse (Phthirus pubis: Anoplura) in the hair of the head. Parasitology, 33, 117-18.

1941. Studies on populations of head-lice (Pediculus humanus capitis: Anoplura). IV. The composition of populations. Parasitology, 33, 224-42.

1941. A map projection of biological interest. Proc. $R$. Ent. Soc. Lond. A, 16, 34.

1941. Discussion on prevention and treatment of parasitic diseases. Some recent work on the louse. Proc. R. Soc. Med. 34, 193-5.

1941. The parasitology of scabies. Brit. Med. J. ii, 397.

1941. The recorded distribution of certain fleas. Bull. Ent. Res. 32, 119-22.

1941. (With J. R. Busvine.) Noxious pests in shelters. Nursing Times, p. 57.

1942. A key to the adult Anopheles mosquitoes of the Mediterranean region and the lands adjoining the Red Sea and Persian Gulf. Duplicated (1942).

1942. A new method of controlling the head louse. Brit. Med. J. i, 464.

1942. (With C. G. Johnson). Ecology of the bed-bug: summary of new knowledge. Spec. Rep. Ser., Med. Res. Coun. no. 245, pp. 6-17.

1944. The entomology of mite-carried typhus. Proc. R. Ent. Soc. Lond. C, 9, 17-18.

1944. Rough notes. Anopheles mosquitoes and malaria in Arabia. Trans. R. Soc. Trop. Med. Hyg. 38, 205-14.

1945. Natural history of scrub typhus. Nature, Lond., 155, 643.

1945. The use of the new insecticide DDT in relation to the problems of tropical medicine. Trans. R. Soc. Trop. Med. Hyg. 38, 367-400.

1945. Experiments with DDT in solutions and emulsions against mosquito larvae in West Africa. Bull. Ent. Res. 36, 165-75.

1946. A plant with sticky seeds which attracts and traps butterflies (Acraea) in Tanganyika. Proc. R. Ent. Soc. Lond. A, 21, 12.

1947. (With J. R. Busvine.) Pests of the animal house and their control. The UFAW Handbook on the Care and Management of Laboratory Animals, pp. 49-64.

1948. Tsetse flies and the development of Africa. Fight. Ag. Dis. 36, 1-7.

1948. The problem of tsetse flies (Glossina). Proc. 4th Int. Congr. Trop. Med. Malaria, Washington, 2, 1630-7.

1948. Relation of tsetse flies to game. East African High Commission. Fauna of British Eastern and Central Africa, Nairobi (1948), Appendix D, 56-66.

1948. Trypanosomiasis in Eastern Africa, 1947. Colonial Office (1948).

1948. Experiments with mice and fleas. I. The baby mouse. Parasitology, 39, 119-24.

1949. Presidential address on control of tsetse flies by human settlement. J. R. Sanit. Inst. 69, 615-16. 
1949. (With H. S. Leeson.) Anopheline mosquitoes. Malariology (M. F. Boyd, ed.), 1, 257-87.

1949. Notes on trypanosomiasis and tsetse in the southern parts of the Anglo-Egyptian Sudan. Bureau permanent interafricain de la tsé-tsé et de la trypanosomiase, Leopoldville (Congo Belge), p. 85.

1952. Research in medical entomology and insecticides. Medicine \& Pathology 1952, pp. 420-7.

1952. Symposium on insecticides. Trans. R. Soc. Trop. Med. Hyg. 46, 213-74.

1953. Note on fungus gnats bred from Myxomycetes. Proc. $R$. Ent. Soc. Lond. A, 17, 55.

1953. (With H. F. Barnes.) British Diptera associated with fungi. 1. Gall midges (Cecidomyidae) reared from the larger fungi. Proc. R. Ent. Soc. Lond. R, 22, 195.

1954. Failure to publish scientific results. Nature, Lond., 173, 410.

1954. British Diptera associated with fungi. 2. Diptera bred from Myxomycetes. Proc. $R$. Ent. Soc. Lond. A, 29, 163-71.

1954. Tsetse and climate: a consideration of the growth of the knowledge. Proc. R. Ent. Soc. Lond. C, 19, 71-8.

1955. Karl Jordan's contribution to our knowledge of fleas associated with disease. Trans. R. Ent. Soc. Lond. 107, 43-4.

\section{BOOKS}

1921. Animal Life in Deserts. London: Arnold.

1927. (With G. H. E. HopkINs.) Researches in Polynesia and Melanesia: Medical Entomology. London School of Hygiene and Tropical Medicine, Memoir no. 1.

1928. Researches in Polynesia and Melanesia: Human Diseases and Welfare. London School of Hygiene and Tropical Medicine, Memoir no. 2.

1939. The Louse. London: Arnold (second edition, 1947).

1954. The Natural History of Tsetse Flies. London School of Hygiene and Tropical Medicine, Memoir no. 10. London: Lewis and Co. 